Ground-Water Resources Program

\title{
Geophysical Log Database for the Mississippi Embayment Regional Aquifer Study (MERAS)
}

Scientific Investigations Report 2008-5192
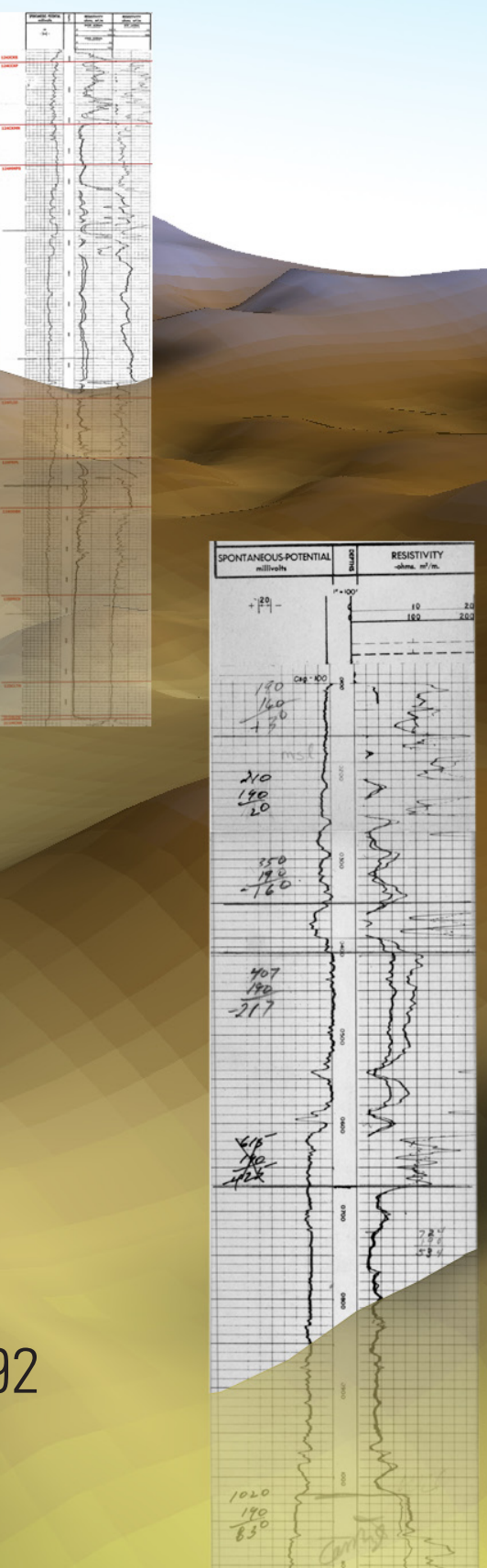

U.S. Department of the Interior U.S. Geological Survey 


\section{Geophysical Log Database for the Mississippi Embayment Regional Aquifer Study (MERAS)}

By Rheannon M. Hart and Brian R. Clark

Ground-Water Resources Program

Scientific Investigations Report 2008-5192 


\section{U.S. Department of the Interior DIRK KEMPTHORNE, Secretary}

\section{U.S. Geological Survey \\ Mark D. Myers, Director}

\section{U.S. Geological Survey, Reston, Virginia: 2008}

For product and ordering information:

World Wide Web: http://www.usgs.gov/pubprod

Telephone: 1-888-ASK-USGS

For more information on the USGS--the Federal source for science about the Earth, its natural and living resources, natural hazards, and the environment:

World Wide Web: http://www.usgs.gov

Telephone: 1-888-ASK-USGS

Any use of trade, product, or firm names is for descriptive purposes only and does not imply endorsement by the U.S. Government.

Although this report is in the public domain, permission must be secured from the individual copyright owners to reproduce any copyrighted materials contained within this report. 


\section{Contents}

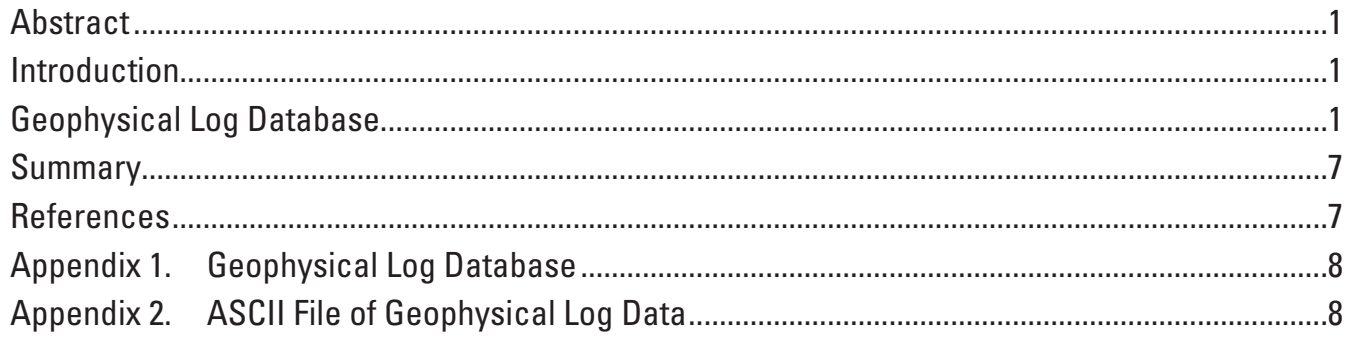

\section{Figures}

1. Map showing geophysical log locations in the Mississippi Embayment Regional Aquifer Study area. .2

2. Example geophysical logs from Arkansas (a), Mississippi (b), and Tennessee (c)..........6

\section{Tables}

1. Hydrogeologic units and their correlation across the States within the Mississippi Embayment Regional Aquifer Study $\ldots 4$

2. Correlation of aquifer codes to hydrogeologic unit names for Mississippi Embayment Regional Aquifer Study framework..

\section{Conversion Factors}

\begin{tabular}{|c|c|c|}
\hline Multiply & By & To obtain \\
\hline \multicolumn{3}{|c|}{ Length } \\
\hline foot $(\mathrm{ft})$ & 0.3048 & meter $(\mathrm{m})$ \\
\hline mile (mi) & 1.609 & kilometer (km) \\
\hline \multicolumn{3}{|c|}{ Area } \\
\hline square mile $\left(\mathrm{mi}^{2}\right)$ & 2.590 & square kilometer $\left(\mathrm{km}^{2)}\right.$ \\
\hline
\end{tabular}

Vertical coordinate information is referenced to the North American Vertical Datum of 1929 (NGVD 29).

Horizontal coordinate information is referenced to the North American Datum of 1983 (NAD 83).

Altitude, as used in this report, refers to distance above or below the vertical datum. 


\title{
Geophysical Log Database for the Mississippi Embayment Regional Aquifer Study (MERAS)
}

\author{
By Rheannon M. Hart and Brian R. Clark
}

\section{Abstract}

The Mississippi Embayment Regional Aquifer Study (MERAS) is an investigation of ground-water availability and sustainability within the Mississippi embayment as part of the U.S. Geological Survey Ground-Water Resources Program. The MERAS area consists of approximately 70,000 square miles and encompasses parts of eight states including Alabama, Arkansas, Illinois, Kentucky, Louisiana, Mississippi, Missouri, and Tennessee. More than 2,600 geophysical logs of test holes and wells within the MERAS area were compiled into a database and were used to develop a digital hydrogeologic framework from land surface to the top of the Midway Group of upper Paleocene age. The purpose of this report is to document, present, and summarize the geophysical log database, as well as to preserve the geophysical logs in a digital image format for online access.

\section{Introduction}

The Mississippi Embayment Regional Aquifer Study (MERAS) began in 2006 to investigate ground-water availability and sustainability within the Mississippi embayment as an initiative of the U.S. Geological Survey (USGS) GroundWater Resources Program (http://water.usgs.gov/ogw/gwrp/). At the onset of the MERAS, one goal was to provide geophysical logs for Federal, State, and local agencies, as well as drillers, consultants, and the public and use the logs to develop a digital hydrogeologic framework for the MERAS area. A similar task was undertaken by the Gulf Coast Regional Aquifer-System Analysis Program of the USGS in the late 1970s to the late 1990s (Grubb, 1986; Wilson and Hosman, 1987). The purpose of this report is to document, present, and summarize the geophysical log database used to develop the digital hydrogeologic framework for the MERAS, and also to preserve the geophysical logs in a digital image format that can be accessed online.
The MERAS area consists of approximately 70,000 $\mathrm{mi}^{2}$ and encompasses parts of eight states including Alabama, Arkansas, Illinois, Kentucky, Louisiana, Mississippi, Missouri, and Tennessee (fig. 1). The Mississippi Embayment aquifer system is composed of alternating beds of Cenozoic-age sand, silt, and clay. The sands are of hydrogeologic significance in that they constitute aquifers of regional and local importance. The clays, on the other hand, typically are the confining units that separate the aquifers. A database was constructed from the information derived from geophysical logs of test holes and wells located within the MERAS area, referred to hereafter as the geophysical log database. As many as 12 hydrogeologic units were considered for interpretation on the geophysical $\operatorname{logs}$, depending on location of the test hole or well; however, the Winona-Tallahatta aquifer was included with the lower Claiborne confining unit and the Old Breastworks confining unit included with the lower Wilcox aquifer for a final interpretation of 10 hydrogeologic units. The geophysical log database then was used to construct a digital hydrogeologic framework (Hart and others, 2008) to support the simulation of ground-water flow within the MERAS area.

\section{Geophysical Log Database}

More than 2,600 geophysical logs within the MERAS area were used to develop a digital hydrogeologic framework that includes the principal hydrogeologic units from land surface to the top of the Midway Group of upper Paleocene age (Hart and others, 2008). The units included in the hydrogeologic framework are the Mississippi River Valley alluvial aquifer, Vicksburg-Jackson confining unit (contained within the Jackson Group), upper Claiborne aquifer (contained within the Claiborne Group), middle Claiborne confining unit (contained within the Claiborne Group), middle Claiborne aquifer (contained within the Claiborne Group), lower Claiborne confining unit (contained within the Claiborne Group), lower Claiborne aquifer (contained within the Claiborne Group), middle Wilcox aquifer (contained within the Wilcox Group), lower Wilcox aquifer (contained within the Wilcox Group), 


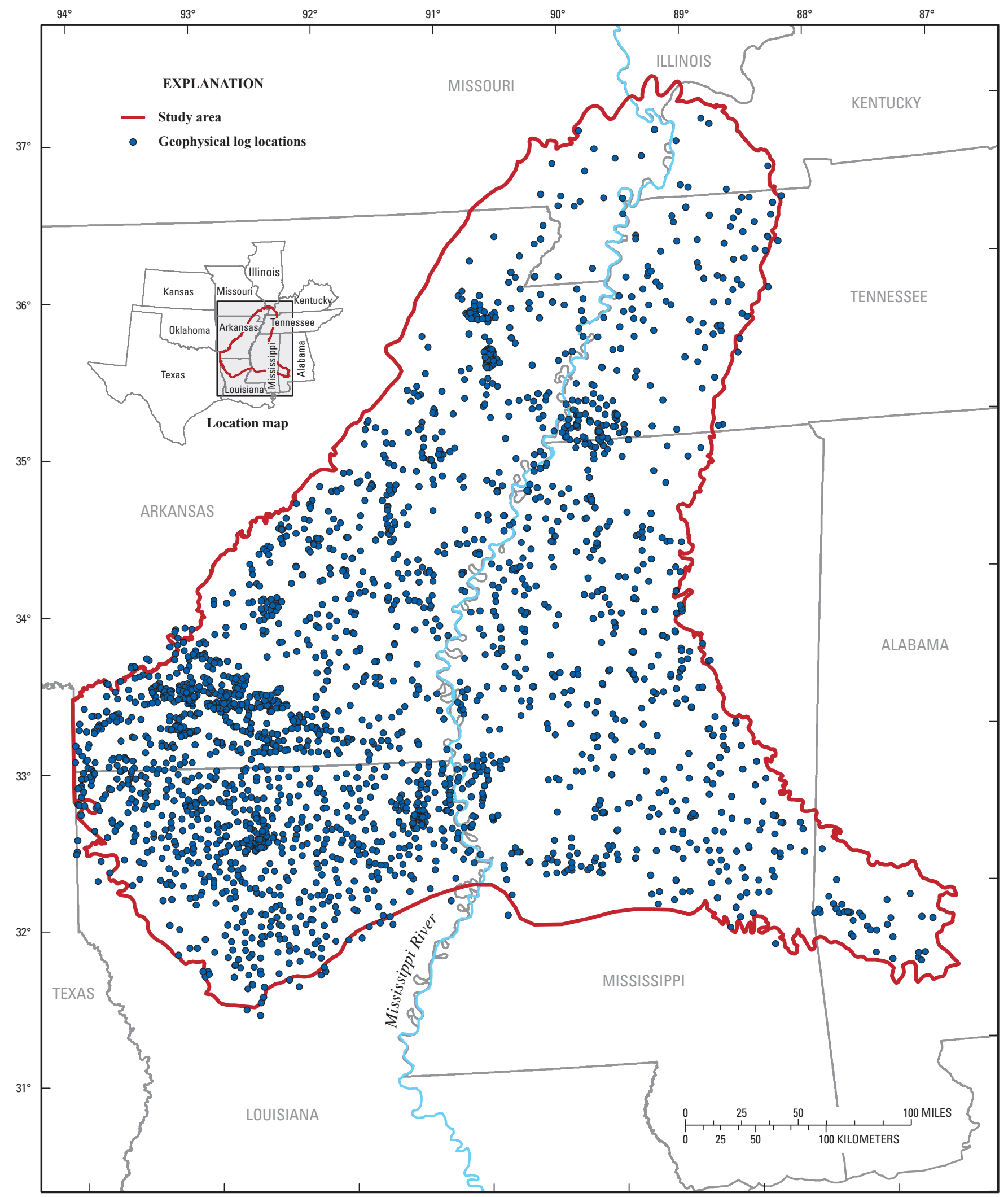

Figure 1. Geophysical log locations in the Mississippi Embayment Regional Aquifer Study area. 
and the Midway confining unit (contained within the Midway Group) (table 1). Geophysical logs were run by various agencies and companies, and copies of the logs were compiled from USGS offices in Alabama, Arkansas, Louisiana, Mississippi, Missouri, and Tennessee and from the Kentucky Geological Survey (KGS) in Lexington, Kentucky. The geophysical logs used for the MERAS were primarily electricalresistivity logs from test holes for petroleum or water wells. In some instances, natural-gamma and spontaneous potential logs exist in addition to the resistivity logs for the same test hole or well. In other instances, natural-gamma logs were all that were available and supplemented the subsurface information in areas where resistivity logs were not available. Geophysical $\operatorname{logs}$ were selected for inclusion based on availability, quality, depth, and spatial distribution within the MERAS area. Some of the included geophysical logs lie outside the MERAS area boundary in Louisiana and Mississippi and were used to assist with correlations of complex lithologies near the study-area boundary, and extend the interpretation of the hydrogeologic units for a more accurate representation of the system.

Paper copies of the geophysical logs were digitally scanned and digital versions of logs were downloaded from the KGS (http://kgsmap.uky.edu/website/KGSGeoPortal/ KGSGeoPortal.asp) in DjVu file format (http:// www.lizardtech.com/). The location of each test hole or well was indentified based on geophysical log header information and was added to a Geographic Information System (GIS). Each geophysical log was given a unique identifier or site number based on the latitude and longitude of the test hole or well.

Determination of the top of each hydrogeologic unit or formation of interest on a geophysical log was made based partly on previously published reports that describe the geohydrologic units of the Gulf Coastal Plain in Arkansas (Petersen and others, 1985), the top of the Sparta Sand and Memphis Sand in Arkansas (Pugh and others, 1998), geohydrologic units of the Mississippi embayment (Hosman and Weiss, 1991), or the stratigraphy and subsurface geology of the Cenozoic deposits in the Gulf Coastal Plain (Hosman, 1996). Contacts between confining units and aquifers can be discernable because of contrasting log response, for example, (124CRVR; fig. 2a), but in some cases, consideration of geophysical logs from several nearby test holes or wells and professional judgment were necessary to pick some aquifers because of complexities caused by numerous interbedded sands or thick sand sequences, for example, (124WNON; fig. 2b). Once the tops of the hydrogeologic units of interest were interpreted on the logs, the depths below land surface of these contacts were entered into the geophysical log database. There are instances where there are more values in the geophysical log database than there are in the log interval. These values were obtained from the Regional Aquifer-System Analysis Program conducted from the late 1970s to the late 1990s (U.S. Geological Survey, 2008). Additionally, depths greater than zero exist for such units as terrace deposits, loess, Mississippi River Valley alluvial aquifer, or other unit considered to be surficial units.
These depths reflect a contact within the surficial unit that is consistent with a sand/clay interface or actual contact between a loess and terrace deposit. Altitudes for each hydrogeologic unit were calculated based on datums provided in the geophysical log header, digital elevation models, topographic maps, or the USGS Ground-Water Site Inventory database (http:// waterdata.usgs.gov/nwis/gwsi).

The hydrogeologic unit interpretations are indicated on the geophysical logs by inserting a line and text indicating the USGS National Water Information System (NWIS) code to which the aquifers and confining units correspond (fig. 2; table 2). The tops of hydrogeologic units within the MERAS area were interpreted by multiple hydrologists in multiple States. Codes used for describing the same hydrogeologic unit often vary among States. Because of this, multiple codes were used for the same hydrogeologic unit on logs from different States (table 2). The geophysical log images were placed in an electronic directory (appendix 1; http://pubs.usgs.gov/ sir/2008/5192) and arranged by State and County, where each State and County is referred to by a code (http://www.epa.gov/ enviro/html/codes/state.html).

For the purposes of this report, the current (2008) geophysical log database is considered to be version 1.0. A version number may be helpful to track future updates to interpretation of hydrogeologic unit tops as more data are acquired and the overall understanding of the subsurface changes.

Basic data from the geophysical log database were extracted to ASCII format (appendix 2) for download from the USGS Publications Warehouse at http://pubs.usgs.gov/ sir/2008/5192. The data in the ASCII file consist of the following fields: unique identifier (site_no), station name (station_nm), latitude (lat), longitude (lon), State and County code (FIPS), geophysical log datum (log_datum), path to log image (url), and the depth to the top of hydrogeologic units used in the MERAS framework (table 2). The geophysical log images also are available from the USGS Publications Warehouse. 


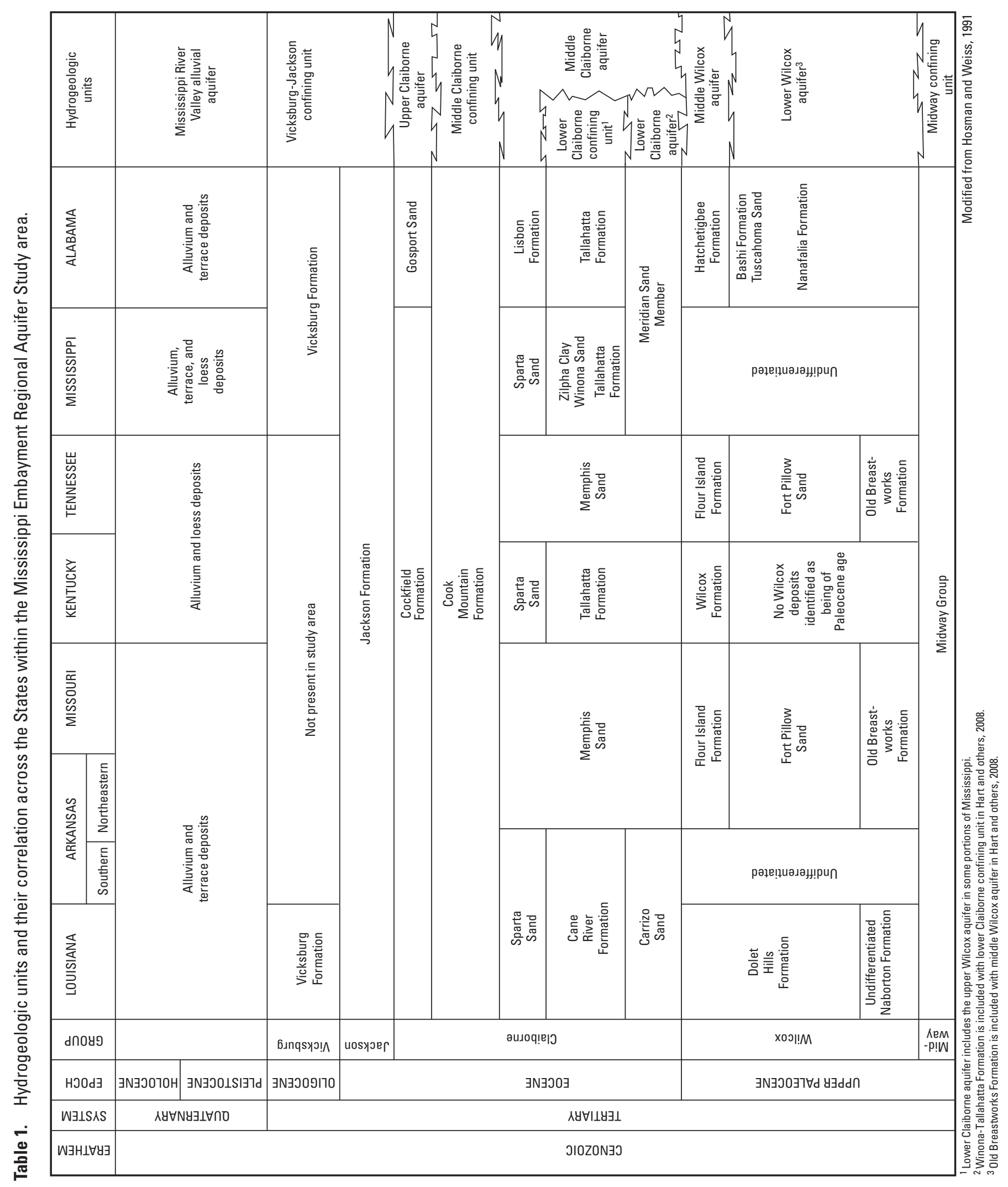


Table 2. Correlation of aquifer codes to hydrogeologic unit names for Mississippi Embayment Regional Aquifer Study framework.

[Aquifer code and formation, lithology, or aquifer name from http://waterdata.usgs.gov/nwis/help/?read_file=local_aqfr\&format=table may not correspond to hydrogeologic unit name from table 1]

\begin{tabular}{|c|c|c|c|}
\hline Hydrogeologic unit name & $\begin{array}{l}\text { Hydrogeologic unit } \\
\text { short name }\end{array}$ & $\begin{array}{l}\text { Formation, lithology or } \\
\text { aquifer name }\end{array}$ & Aquifer code \\
\hline $\begin{array}{l}\text { Mississippi River Valley } \\
\text { alluvial aquifer }\end{array}$ & \multirow{3}{*}{ MRVA } & $\begin{array}{c}\text { Alluvium, Quaternary alluvium, } \\
\text { Mississippi River Valley alluvial } \\
\text { aquifer, Red River Valley } \\
\text { alluvium }\end{array}$ & $\begin{array}{l}\text { 110ALVM } \\
112 \mathrm{ALVM} \\
110 \mathrm{QRNR} \\
112 \mathrm{MRVA} \\
112 \mathrm{RRVA}\end{array}$ \\
\hline $\begin{array}{l}\text { Mississippi River Valley } \\
\text { alluvial aquifer }\end{array}$ & & Pleistocene Series, Loess & $\begin{array}{l}\text { 112PLSC } \\
112 \mathrm{LOSS}\end{array}$ \\
\hline $\begin{array}{l}\text { Mississippi River Valley } \\
\text { alluvial aquifer }\end{array}$ & & $\begin{array}{l}\text { Terrace Deposits, } \\
\text { Upland terrace deposits }\end{array}$ & $\begin{array}{l}\text { 112TRRC } \\
\text { 112UPTC }\end{array}$ \\
\hline $\begin{array}{l}\text { Vicksburg-Jackson } \\
\text { confining unit }\end{array}$ & VKBG & Vicksburg-Jackson Group & $\begin{array}{l}123 \mathrm{VKBG} \\
124 \mathrm{JCKS}\end{array}$ \\
\hline Upper Claiborne aquifer & UCAQ & $\begin{array}{l}\text { Cockfield Formation of } \\
\text { Claiborne Group }\end{array}$ & $\begin{array}{l}124 \mathrm{CCKF} \\
124 \mathrm{CLBR}\end{array}$ \\
\hline Middle Claiborne confining unit & $\mathrm{MCCU}$ & $\begin{array}{c}\text { Cook Mountain Formation } \\
\text { of Claiborne Group }\end{array}$ & $124 \mathrm{CKMN}$ \\
\hline Middle Claiborne aquifer & MCAQ & $\begin{array}{c}\text { Sparta Sand of Claiborne Group, } \\
\text { Memphis aquifer (500-Foot } \\
\text { Sand), Memphis Sand }\end{array}$ & $\begin{array}{c}\text { 124SPRT } \\
12405 \mathrm{MP} \\
124 \mathrm{MMPS}\end{array}$ \\
\hline Lower Claiborne confining unit & $\mathrm{LCCU}$ & $\begin{array}{c}\text { Cane River Formation of } \\
\text { Claiborne Group, Zilpha Clay }\end{array}$ & $\begin{array}{l}\text { 124CRVR } \\
124 \mathrm{ZLPH}\end{array}$ \\
\hline${ }^{1}$ Winona-Tallahatta aquifer & WNTH & Winona-Tallahatta Formation & $\begin{array}{c}124 \mathrm{WNON} \\
124 \mathrm{TLLT} \\
\end{array}$ \\
\hline${ }^{2}$ Lower Claiborne aquifer & LCAQ & $\begin{array}{c}\text { Carrizo Sand of Claiborne } \\
\text { Group, Meridian Sand of } \\
\text { Tallahatta Formation, Meridian- } \\
\text { Upper Wilcox aquifer }\end{array}$ & $\begin{array}{c}\text { 124CRRZ } \\
\text { 124MRDN } \\
\text { 124MUWX }\end{array}$ \\
\hline Middle Wilcox aquifer & MWAQ & $\begin{array}{l}\text { Wilcox Group, Flour Island } \\
\text { Formation of Wilcox Group, } \\
\text { Middle Wilcox aquifer }\end{array}$ & $\begin{array}{c}\text { 124WLCX } \\
\text { 124FLID } \\
\text { 124WLCXM }\end{array}$ \\
\hline Lower Wilcox aquifer & LWAQ & $\begin{array}{l}\text { Fort Pillow Sand (1,400-Foot } \\
\text { Sand) of Wilcox Group, Lower } \\
\text { Wilcox aquifer }\end{array}$ & $\begin{array}{c}\text { 124FRPL } \\
\text { 124WLCXL }\end{array}$ \\
\hline${ }^{3}$ Old Breastworks confining unit & ODBK & Old Breastworks Formation & 124ODBK \\
\hline Midway confining unit & MDWY & $\begin{array}{c}\text { Midway Group, Porters } \\
\text { Creek Clay }\end{array}$ & $\begin{array}{l}\text { 125MDWY } \\
125 \mathrm{PRCK}\end{array}$ \\
\hline
\end{tabular}

${ }^{1}$ Winona-Tallahatta aquifer is included with Lower Claiborne confining unit in Hart and others, 2008.

${ }^{2}$ Lower Claiborne aquifer includes the upper Wilcox aquifer in some portions of Mississippi.

${ }^{3}$ Old Breastworks confining unit is included with lower Wilcox aquifer in Hart and others, 2008.

Note: Hydrogeologic units, formations, and aquifers shown above were grouped to form hydrogeologic units with "short" names to facilitate the MERAS ground-water flow model. This grouping does not imply that all formations or aquifers shown in the two right-hand columns exist in each State in the MERAS area. 

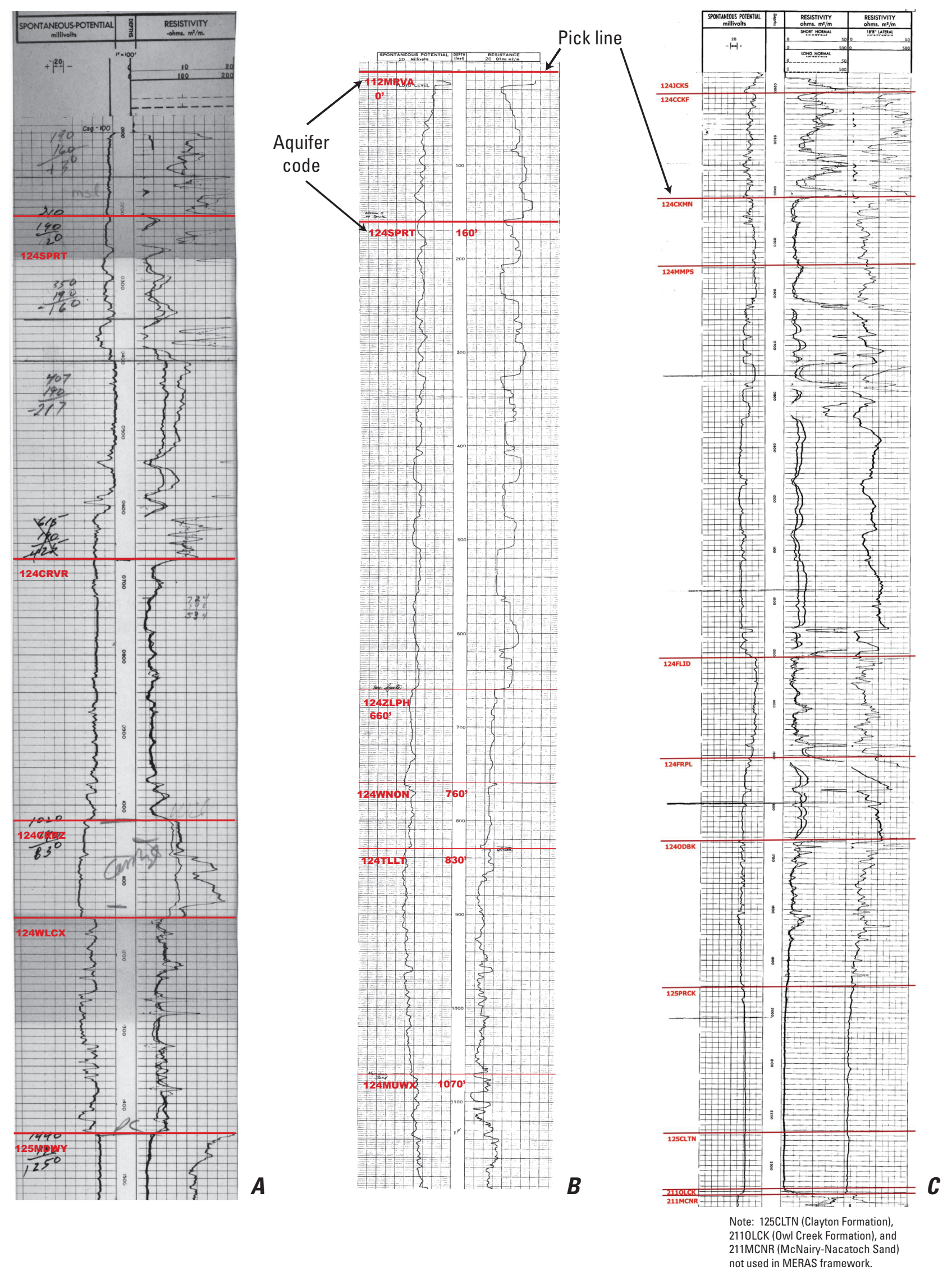

Figure 2. Example geophysical logs from Arkansas (a), Mississippi (b), and Tennessee (c) (not to scale). 


\section{Summary}

The MERAS is an investigation of ground-water availability and sustainability within the Mississippi embayment as part of the U.S. Geological Survey Ground-Water Resources Program. More than 2,600 geophysical logs of test holes and wells within the MERAS area were compiled and used to develop a digital hydrogeologic framework of the area which includes the principal hydrogeologic units from land surface to the top of the Midway Group of upper Paleocene age. The digital framework was constructed to support the simulation of ground-water flow within the MERAS area.

Paper copies of the geophysical logs were compiled from USGS offices in Alabama, Arkansas, Louisiana, Mississippi, Missouri, and Tennessee and downloaded from the Kentucky Geological Survey. Determination of the top of each hydrogeologic unit of interest on a geophysical log was made based partly on previously published reports for the Mississippi embayment. After the tops of the hydrogeologic units of interest were interpreted on the logs, the depths below land surface of each hydrogeologic unit were entered into the geophysical log database. The hydrogeologic unit interpretations were indicated on the geophysical logs by inserting a line and text indicating the National Water Information System codes to which the aquifers and confining units correspond. The geophysical-log database and images are placed in an electronic directory and arranged by State and County. The geophysical log database and images are downloadable from the U.S Geological Survey Publications Warehouse.

\section{References}

Grubb, H.F., 1986, Gulf Coastal Plain Regional AquiferSystem Study, in Sun, R.J., ed., Regional Aquifer-System Analysis Program of the U.S. Geological Survey - summary of projects, 1878-84: U.S. Geological Survey Circular 1002, p. $152-161$.

Hart, R.M., Clark, B.R., and Bolyard, S.E., 2008, Digital hydrogeologic surface and thickness of the Mississippi Embayment Regional Aquifer Study (MERAS) area: U.S. Geological Survey Scientific Investigations Report 20085098, accessed December 4, 2008, at http://pubs.er.usgs. gov/usgspubs/sir/sir20085098

Hosman, R.L., 1996, Regional stratigraphy and subsurface geology of Cenozoic deposits, Gulf Coastal Plain, SouthCentral United States: U.S. Geological Survey Professional Paper 1416-G, 35 p.

Hosman, R.L., and Weiss, J.S., 1991, Geohydrologic units of the Mississippi Embayment and Texas Coastal Uplands aquifer systems, South-Central United States: U.S. Geological Survey Professional Paper 1416-B, 19 p.
Petersen J.C., Broom, M.E., and Bush, W.V., 1985, Geohydrologic units of the Gulf Coastal Plain in Arkansas: U.S. Geological Survey Water-Resources Investigations Report 85-4116, 20 p.

Pugh, A.L., Westerfield, P.W., Gonthier, G.J., and Poynter, D.T., 1998, Altitude of the top of the Sparta Sand and Memphis Sand in three areas of Arkansas: U.S. Geological Survey Water-Resources Investigations Report 98-4002, 5 p.

U.S. Geological Survey, 2008, Office of Ground Water (OGW), accessed October 15, 2008, at http://water.usgs. gov/cgi/rasabiblio/?category=11\&form=introduction.

Wilson, T.A. and Hosman, R.L., 1987, Geophysical well-log data base for the Gulf Coast Aquifer Systems, south-central United States: U.S. Geological Survey Open-File Report 87-677, 213 p. 


\section{Appendix 1. Geophysical Log Database}

The geophysical log images are placed in an electronic directory (http://pubs.usgs.gov/sir/2008/5192) and arranged by State and County, where each State and county is referred to by a code (http://www.epa.gov/enviro/html/codes/state.html).

\section{Appendix 2. ASCII File of Geophysical Log Data}

Basic data from the geophysical-log database were extracted to ASCII format for download from the USGS Publications Warehouse at http://pubs.usgs.gov/sir/2008/5192. The data in the ASCII file consist of unique identifier (site_no); station name (station_nm); latitude (lat); longitude (lon); State and county code (FIPS); log datum (log_datum), in feet; path to log image (url); and the depth to the top of hydrogeologic units (codes listed in table 2 of this report), in feet. 
Publishing support provided by:

Lafayette and Rolla Publishing Service Centers

For more information concerning the research described in the report:

U.S. Geological Survey

Arkansas Water Science Center

401 Hardin Road

Little Rock, AR 72211-3528

(501) 228-3600

http://ar.water.usgs.gov 
